\title{
THE MERCURY (Hg) CONCENTRATIONS IN FEATHERS OF WILD BIRDS
}

\author{
DURMUȘ, A. \\ Department of Biology, Science Faculty, Van Yuzuncu Yil University, 65080 Van, Turkey \\ (e-mail: atilla@yyu.edu.tr) \\ (Received $19^{\text {th }}$ Feb 2018; accepted $9^{\text {th }}$ May 2018)
}

\begin{abstract}
In this study, mercury ( $\mathrm{Hg}$ ) concentrations were detected in feathers of 22 bird species from 10 different families living in terrestrial and aquatic ecosystems in Van Lake Basin in Turkey. The mercury rates in feathers were detected based on nutrition status and taxonomic classifications of bird species. Mercury levels were detected in $0.002 \pm 0.007 \mathrm{mg} / \mathrm{kg}$ and $2.700 \pm 0.560 \mathrm{mg} / \mathrm{kg}$ dry weight range. It was observed that there was a significant difference between the groups classified taxonomically $(\mathrm{p}<0.05)$. The highest concentrations were detected in European Honey-buzzard (Pernis apivorus) $2.7 \mathrm{mg} / \mathrm{kg}$, Lammergeier (Gypaetus barbatus) $0.45 \mathrm{mg} / \mathrm{kg}$ and Long-legged Buzzard (Buteo rufinus) $0.28 \mathrm{mg} / \mathrm{kg}$ species from Accipitridae family. And the lowest mercury concentration was detected in Golden Eagle (Aquila chrysaetos) from the same family $(0.002 \pm 0.007 \mathrm{mg} / \mathrm{kg})$. Mercury was detected in the feather samples taken from the Egyptian Vulture, Lammergeier, Northern Lapwing, and Great Bustard, and these species were determined to be within different endangered categories according to the International Union for Conservation Nature (IUCN). Considering the trophic level (type of food) and systematic groups of the sampled species, it was determined that average mercury level was statistically significant in both cases. It was suggested that the mercury level of the carnivorous ones were higher than that of the herbivorous ones.
\end{abstract}

Keywords: heavy metal, raptor birds, toxicology, endangered, East Anatolia, Turkey

\section{Introduction}

Most heavy metals play an important role in the lives of living species. Heavy metals as an integral part of nature must be present in the structure of all living creatures in trace levels. If, these trace levels are exceeded, it shows toxic effect in the organism (Zolfaghari et al., 2007; Manjula et al., 2015).

As a result of developing technology and increasing human population, natural resources are consumed exceedingly and in consequence, overmuch waste is discharged into the nature. These wastes exceeding the bearing capacity of the nature accumulate in bodies of living species within the food web of the ecosystem through nutrition and environmental contact and consequently create risk (Nriagu and Pacyna, 1988; Dudka and Miller, 1999; Metcheva et al., 2010). The best indicator of a biological pollution of an environment is analyzing the creatures living in that environment and detecting toxic materials accumulated in their bodies.

Birds are ideal bio-indicator animals showing the best reaction about the structure of an ecosystem they live in. Analyzing these species located on the upper of the food web provides information on the status and condition of the related ecosystem (Burger, 1993). While, conducting these studies, present species should not be harmed in anyway. Therefore, analyzing the feathers taken from their bodies provides information on heavy metal rate of their environment. This does not only provide information on heavy metal concentrations in bird species but also the heavy metal concentrations in other living creatures under lower steps of the food web of birds which are foods of them (Battaglia et al., 2005). 
The metals taken by birds through nutrition during their growth are carried to their feathers through blood vessels and accumulate there by bonding with protein molecules (Burger, 1993; Dauwe et al., 2000; Goutner et al., 2001; Dauwe et al., 2003). The source of heavy metal concentrations in feathers is not only nutrition, but also some environmental factors such as contact with soil, water, atmospheric pollution and precipitations (Burger and Gochfeld, 1997; Movalli, 2000; Jasper et al., 2004; Muralidharan et al., 2004; Cardiel et al., 2011).

Using feathers for detecting heavy metals such as mercury provides advantages compared to other tissues (Furness et al., 1986, 1989; Burger, 1996; Movalli, 2000). These advantages are taking feather samples from living creatures without harming them, storing feathers easily and preserving them for a long time in a refrigerator without needing anything.

The purpose of this study is to determine the amount of mercury accumulated in structures of the birds located at an upper step of food web and living in different ecosystems of Van Lake Basin (Turkey) through nutrition. It is to reveal the differences between mercury concentrations by considering the birds' nutrition styles and places in systematic category.

\section{Materials and methods}

The feather samples used in this study were taken from 102 birds from 22 bird species. 22 bird species used in this study are the resident and migratory species living in aquatic and terrestrial ecosystems of Van Lake Basin (Fig.1; Adizel et al., 2010; Nergiz and Durmuş, 2017).

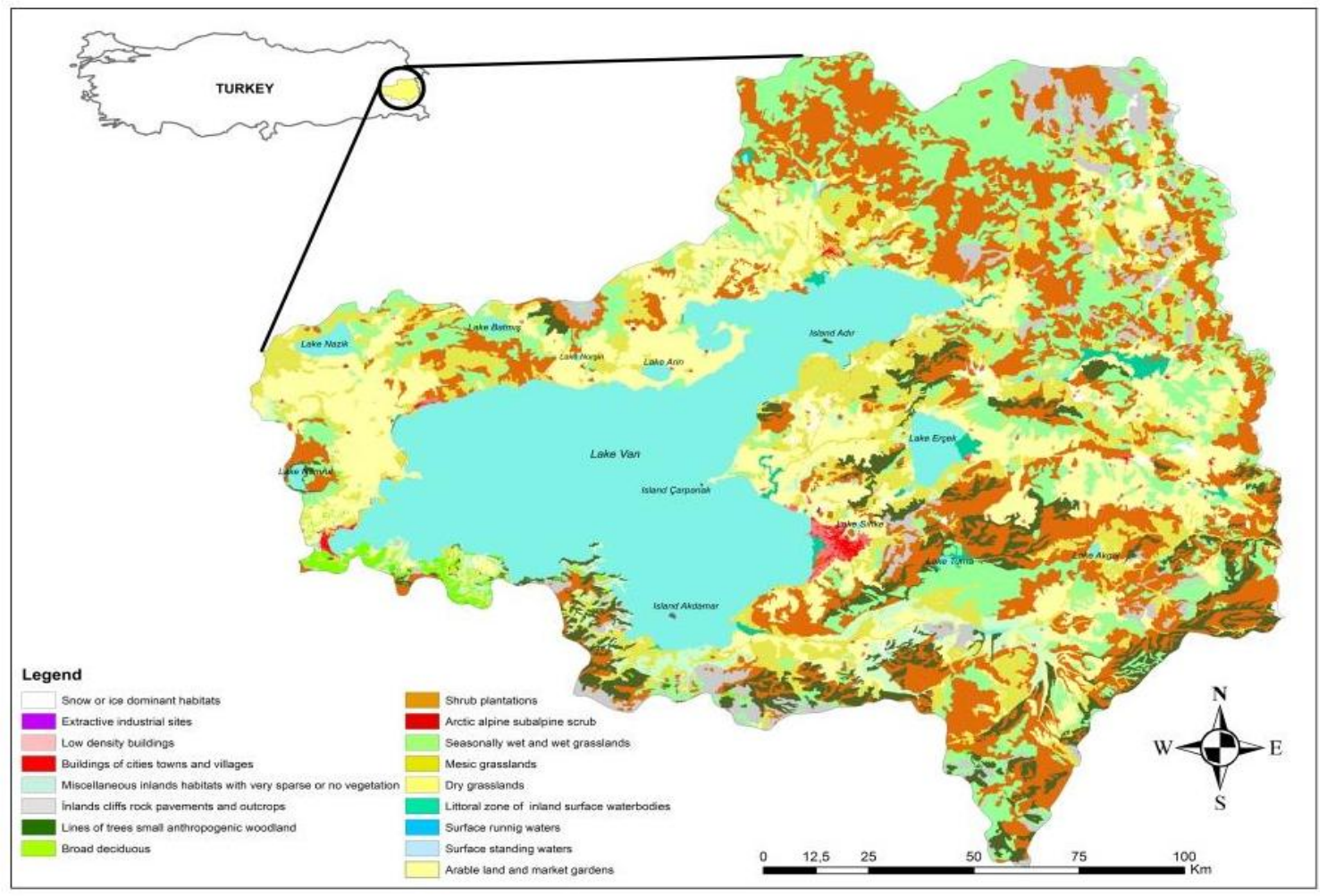

Figure 1. Van Lake Basin and habitat types 
These species were found injured or diseased in their ecosystems, taken to the Rehabilitation Center for Wild Animals of Van Yuzuncu Yil University, treated but then died. The feather samples were taken from these birds died between May 2016 and June 2017. Half of the sampled species were raptors.

\section{Analysis of samples}

The samples were transferred to the Science Application and Research Center of Van Yuzuncu Yil University for analysis. Feathers were washed with deionized water and acetone three times and then put in metal free polypropylene vials. All external pollution available in the feathers can be removed by washing the samples (Goede and Bruin, 1984).

The weights of the dry feather samples were detected and then they were put in an oven $\left(70{ }^{\circ} \mathrm{C}\right)$ for $24 \mathrm{~h}$. The dried feathers were cut with steel scissors and weighed on a precision scale at least $2 \mathrm{~g}$ (dry weight) from each sample and placed in glass containers. The prepared feather samples were burned with the tissue sample program in a microwave heating unit (Ethos Easy Advanced Microwave Digestion System, Milestone, $230 / 50 \mathrm{~Hz}$, Italy) by adding $8 \mathrm{ml}$ of $65 \% \mathrm{HNO}_{3}$ and $2 \mathrm{ml}$ of $\mathrm{H}_{2} \mathrm{O}_{2}$ (Blust et al., 1988; Janssens et al., 2001). The $2 \mathrm{ml}$ solution from the incinerated samples was diluted with distilled water to $10 \mathrm{ml}$ and analyzed on the ICP-AAS (Thermo Scientific ICAP 600 series) instrument.

Calibration of the instrument was done with a certified solution (Multi element ICP QC standard solution-QCS-01-23E, Belgium). Mercury checked by National Institute of Standards and Technology (NIST) and Standard Reference Material (SRM). Accepted recoveries ranged from 95 to $105 \%$.

\section{Statistical analysis}

The statistical analysis was done by the SPSS software (Version 23). Means and standard deviations were given in tables. We used one-way ANOVA and Tukey posthoc comparison for evaluate effects of systematic categories and food manner on feather Mercury $(\mathrm{Hg})$ levels.

\section{Results and discussion}

Average mercury concentrations in feather samples taken from 102 birds from 22 species and 10 families were taxonomically compared (Tables 1-3). Different levels of mercury were detected in all samples. According to the statistical analysis with $95 \%$ confidence range conducted in accordance with the trophic levels and taxonomic groups, it was observed that there were meaningful differences $(p<0.05)$.

The average mercury concentration varied from $0.002 \mathrm{mg} / \mathrm{kg}$ (Golden eagle) to $2.7 \mathrm{mg} / \mathrm{kg}$-dry weight (European Honey-buzzard) (Table 1). The order of ten families from higher to lower $\mathrm{Hg}$ concentration is as follows: Accipitridae, Phasianidae, Otididae, Phoenicopteridae, Ardeidae, Falconidae, Strigidae, Anatidae, Ciconiidae, Charadriidae were compared (Table 2).

In the taxonomic evaluation conducted among the families, it was determined that the Accipitridae family had the highest mercury concentration while the Charadriidae had the lowest mercury concentration. It was observed that these differences between families were based on the nutrition and environmental differences between species. 
Table 1. Mercury concentration ( $\mathrm{mg} / \mathrm{kg}$ dry weight) in feather of birds from eastern Turkey

\begin{tabular}{|c|c|c|c|c|c|}
\hline Family & $\begin{array}{c}\text { Species common } \\
\text { name }\end{array}$ & Scientific name & Number & Trophic level & $\begin{array}{l}\text { Hg concentration } \\
\text { mean } \pm \text { std error }\end{array}$ \\
\hline \multirow[t]{8}{*}{ Accipitridae } & $\begin{array}{c}\text { European Honey- } \\
\text { buzzard }\end{array}$ & Pernis apivorus & 4 & Carnivor & $2.700 \pm 0.560$ \\
\hline & Lammergeier & Gypaetus barbatus & 3 & Carnivor & $0.450 \pm 0.370$ \\
\hline & Egyptian Vulture & $\begin{array}{l}\text { Neophron } \\
\text { percnopterus }\end{array}$ & 4 & Carnivor & $0.033 \pm 0.001$ \\
\hline & Griffon Vulture & Gyps fulvus & 4 & Carnivor & $0.019 \pm 0.002$ \\
\hline & $\begin{array}{l}\text { Western Marsh- } \\
\text { harrier }\end{array}$ & Circus aeruginosus & 5 & Carnivor & $0.050 \pm 0.033$ \\
\hline & $\begin{array}{l}\text { Long-legged } \\
\text { Buzzard }\end{array}$ & Buteo rufinus & 6 & Carnivor & $0.280 \pm 0.170$ \\
\hline & Golden Eagle & Aquila chrysaetos & 3 & Carnivor & $0.002 \pm 0.007$ \\
\hline & $\begin{array}{l}\text { White-tailed } \\
\text { Eagle }\end{array}$ & Haliaeetus albicilla & 4 & Carnivor & $0.015 \pm 0.001$ \\
\hline Falconidae & Common Kestrel & Falco tinnunculus & 5 & Carnivor & $0.054 \pm 0.007$ \\
\hline Strigidae & $\begin{array}{l}\text { Eurasian Eagle- } \\
\text { owl }\end{array}$ & Bubo bubo & 3 & Carnivor & $0.050 \pm 0.030$ \\
\hline Ciconiidae & White Stork & Ciconia ciconia & 4 & Mix feed & $0.012 \pm 0.001$ \\
\hline Phoenicopteridae & Greater Flamingo & $\begin{array}{l}\text { Phoenicopterus } \\
\text { roseus }\end{array}$ & 8 & $\begin{array}{l}\text { Invertebrate } \\
\text { predator }\end{array}$ & $0.130 \pm 0.460$ \\
\hline \multirow[t]{4}{*}{ Ardeidae } & Grey Heron & Ardea cinerea & 5 & Mix feed & $0.220 \pm 0.140$ \\
\hline & Great Bittern & Botaurus stellaris & 6 & Mix feed & $0.112 \pm 0.019$ \\
\hline & Little Egret & Egretta garzetta & 6 & Mix feed & $0.090 \pm 0.030$ \\
\hline & $\begin{array}{l}\text { Black-crowned } \\
\text { Night-heron }\end{array}$ & $\begin{array}{l}\text { Nycticorax } \\
\text { nycticorax }\end{array}$ & 7 & Mix feed & $0.040 \pm 0.003$ \\
\hline Charadriidae & Northern Lapwing & Vanellus vanellus & 3 & $\begin{array}{l}\text { Invertebrate } \\
\text { predator }\end{array}$ & $0.020 \pm 0.001$ \\
\hline Phasianidae & Grey Partridge & Perdix perdix & 5 & Herbivor & $0.150 \pm 0.020$ \\
\hline Otididae & Great Bustard & Otis tarda & 2 & Herbivor & $0.140 \pm 0.010$ \\
\hline \multirow[t]{3}{*}{ Anatidae } & Common Teal & Anas crecca & 6 & Herbivor & $0.020 \pm 0.002$ \\
\hline & Ruddy Shelduck & Tadorna ferruginea & 5 & Herbivor & $0.030 \pm 0.010$ \\
\hline & Northern Pintail & Anas acuta & 4 & Herbivor & $0.010 \pm 0.001$ \\
\hline
\end{tabular}

Table 2. Mercury concentration ( $\mathrm{mg} / \mathrm{kg}$ dry weight) in the feathers according to families

\begin{tabular}{c|c|c|c|c|c|c}
\hline \multirow{2}{*}{ Family } & \multirow{2}{*}{ Number } & \multirow{2}{*}{ Mean } & \multirow{2}{*}{ Std. d. } & \multirow{2}{*}{$\mathbf{p}$} & \multicolumn{2}{|c}{$\mathbf{9 5 \%}$ confidence interval for mean } \\
\cline { 5 - 7 } & & & & Lower & Upper \\
\hline Accipitridae & 33 & 0.432 & 0.167 & 0.015 & 0.091 & 0.773 \\
Phasianidae & 5 & 0.146 & 0.036 & 0.001 & 0.101 & 0.190 \\
Otididae & 2 & 0.140 & 0.028 & 0.090 & -0.114 & 0.394 \\
Phoenicopteridae & 8 & 0.131 & 0.046 & 0.026 & 0.021 & 0.240 \\
Ardeidae & 24 & 0.108 & 0.159 & 0.003 & 0.040 & 0.175 \\
Falconidae & 5 & 0.053 & 0.015 & 0.002 & 0.033 & 0.073 \\
Strigidae & 3 & 0.049 & 0.061 & 0.298 & -0.102 & 0.201 \\
Anatidae & 15 & 0.016 & 0.014 & 0.001 & 0.007 & 0.023 \\
Ciconiidae & 4 & 0.012 & 0.003 & 0.005 & 0.006 & 0.017 \\
Charadriidae & 3 & 0.011 & 0.002 & 0.015 & 0.004 & 0.016 \\
\hline
\end{tabular}

One-way ANOVA followed by Tukey's comparison between islands and water concentrations of metals. Significance level of $\mathrm{p}<0.005$ was used 
The highest $\mathrm{Hg}$ concentration determined in European Honey-buzzard $(2.7 \mathrm{mg} / \mathrm{kg}$ ), Lammergeier $(0.45 \mathrm{mg} / \mathrm{kg})$, and Long-legged Buzzard $(0.28 \mathrm{mg} / \mathrm{kg})$ belonging to Accipitridae family and Grey Heron (0.22 mg/kg-Ardeidae). Intermediate $\mathrm{Hg}$ concentration values were found in Grey Partridge (Phasianidae), Great Bustard (Otididae), Greater Flamingo (Phoenicopteridae), Great Bittern (Ardeidae), Little Egret (Ardeidae), Common Kestrel (Falconidae), Western Marsh-harrier (Accipitridae), Eurasian Eagle-owl (Strigidae), Black-crowned Night-heron (Ardeidae), Egyptian Vulture (Accipitridae), Ruddy Shelduck (Anatidae), Common Teal (Anatidae), Northern Lapwing (Charadriidae), and Griffon Vulture (Accipitridae) species; whereas the lowest $\mathrm{Hg}$ concentration values were found in White-tailed Eagle (Accipitridae), White Stork (Ciconiidae), Northern Pintail (Anatidae), and Golden Eagle (Accipitridae) species.

Birds of prey families (Accipitridae, Falconidae and Strigidae) have more than 2.5 times higher average $\mathrm{Hg}$ concentrations (overall average of average $0.178 \mathrm{mg} / \mathrm{kg}$ ) than the rest of other families (overall average of average $0.08 \mathrm{mg} / \mathrm{kg}$ ) (Table 2). With the exception of Strigidae and Otididae families, there was significant difference in other families $(\mathrm{p}<0.05)$.

According to trophic level, species were separated into 4 classes as Carnivorous (41 samples belonging to 10 species), mix (vertebrate and invertebrate predator, 28 samples belonging to 5 species), invertebrate predators (11 samples belonging to 2 species) and herbivore (22 samples belonging to 5 species) (Table 3; Fig. 2).

Table 3. Mercury concentration ( $\mathrm{mg} / \mathrm{kg}$ dry weight) in the trophic level of birds

\begin{tabular}{c|c|c|c|c|c|c}
\hline Family & \multirow{2}{*}{ Number } & Mean & Std. d. & $\mathbf{p}$ & \multicolumn{2}{|c|}{ 95\% confidence interval for mean } \\
\cline { 5 - 6 } & & & & & Lower & Upper \\
\hline Carnivore & 41 & 0.358 & 0.136 & 0.012 & 0.082 & 0.633 \\
Mix (vertebrate and & 28 & 0.098 & 0.024 & 0.003 & 0.015 & 0.181 \\
invertebrate predator) & 11 & 0.095 & 0.028 & 0.025 & 0.035 & 0.152 \\
Invertebrate predator & 22 & 0.056 & 0.013 & 0.001 & 0.027 & 0.085 \\
\hline
\end{tabular}

One-way ANOVA followed by Tukey's comparison between islands and water concentrations of metals. Significance level of $\mathrm{p}<0.005$ was used

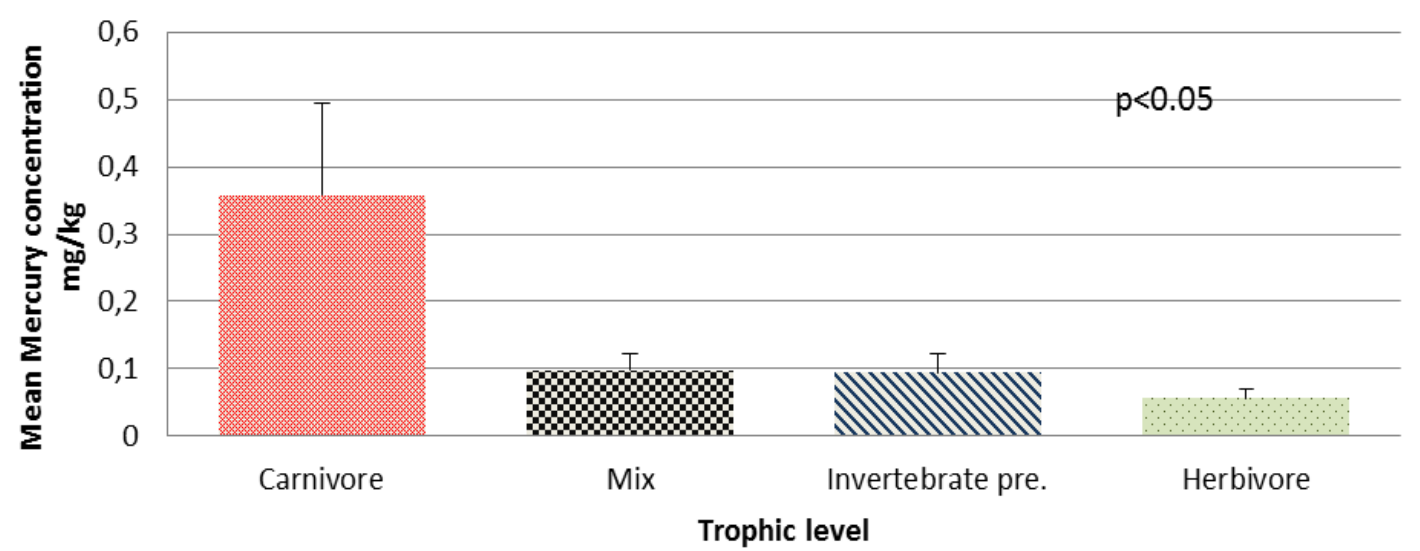

Figure 2. Mercury $(\mathrm{Hg})$ concentration in trophic levels 
Accipitridae, Falconidae, and Strigidae families which eat vertebrates provided the highest mean mercury concentration in feathers $(0.358 \mathrm{mg} / \mathrm{kg})$, whereas the lowest mean $\mathrm{Hg}$ concentration value was found in the feathers of herbivorous birds $(0.056$ $\mathrm{mg} / \mathrm{kg}$ ).

Additionally, Mercury (hg) was detected in the feather samples taken from the Egyptian Vulture, Lammergeier, Northern Lapwing, and Great Bustard, and these species were determined to be within different endangered categories according to the International Union for Conservation Nature (IUCN). Related these species no work was done in Turkey. Egyptian Vulture listed in Endangered (EN) category in IUCN has mercury concentration of $0.033 \mathrm{mg} / \mathrm{kg}$, Lammergeier and Northern Lapwing listed in Near Threatened (NT) have mercury concentrations of $0.45 \mathrm{mg} / \mathrm{kg}$ and $0.02 \mathrm{mg} / \mathrm{kg}$, respectively. Great Bustard listed in Vulnerable (VU) category has mercury concentration of $0.14 \mathrm{mg} / \mathrm{kg}$. In the literature $\mathrm{Hg}$ concentration was determined as 0.055-0.139 ppm (Xiuhua et al., 1998).

In the analysis and studies, it was observed that taxonomically different mercury $(\mathrm{Hg})$ levels were influenced species-related factors such as age, gender and etc. and from environmental factors such as climate (Monteiro and Furness, 1995). However, the individuals taken as samples in our study were completely adults and the same gender so no difference was observed in specie-related individual variations. It was suggested that climatic factors and consequent migration activities as well as pubescence influence mercury concentration (Stewart et al., 1999; Mashroofeh et al., 2015). The species sampled in this study are the species which have not influenced from migration activities, yet, have been present in the region since last spring and the resident ones permanent in the field. Organic mercury is stored at the bottom of feathers grown post incubation period based on nutrition density (Zolfaghari et al,. 2007).

Several studies indicate that the mercury concentration in feathers vary based on types of nutrition and the environment where species are present (Braune and Gaskin, 1987; Cifuentes et al., 2003; Burger, 2013). Especially, the raptors at the top of food web are influenced more from bio-accumulation as they always have carnivorous food. Within this respect, they are more sensitive and under higher risk than other bird species.

In our study, mercury concentration was detected in the samples from all taxonomic groups. However, it was observed that the mercury concentration levels in Accipitridae family covering raptors has significantly higher mercury concentration compared to other families ( $<$ 0.05; Table 3). In general, although, mercury concentration is high in raptors, the concentration was found the lowest in White-tailed Eagle and Golden Eagle species (Table 1). It is because that these species live in high-altitude natural areas and stay away from pollutive fields with anthropogenic source.

According to a study based on Family taxonomy which was conducted in Iran as the closest country to the study region, the highest mercury concentration was detected in Strigidae family $(0.88 \mathrm{mg} / \mathrm{kg}$ ) (Zolfaghari et al., 2007), in our study, the value for this family was $0.05 \mathrm{mg} / \mathrm{kg}$. In the same study, average mercury concentration detected for the Accipitridae family was $1.25 \mathrm{mg} / \mathrm{kg}$ while, in our study, the value for this family was about two times higher and detected as $2.7 \mathrm{mg} / \mathrm{kg}$. In both studies, the lowest concentration value was detected in the Charadriidae family. The reasons of basic differences between these two studies conducted in close regions are different numbers of sampled individuals and density of pollutant factors in nutrition environment of species. 
Mercury level also varies between the Carnivorous species based on types of nutrients. Concentration differences may be observed on the birds consuming high amounts of fish or the ones eating large fish. In the study, it was observed that the species of Ardeidae family have higher levels of mercury concentration compared with the members of another family which eats little fish (Burger, 2002). However, the level of mercury concentration detected in the members of Ardeidae family is around midlevel, not high.

The bird species feeding on primary producers such as vegetal nutrients, seeds, leaves, roots, fruits and algae are the group which are influenced the least from environmental pollutants (Zolfaghari et al.,2007; Behrooz et al.,2009). Parallel to other studies on this subject, the mercury concentration level was also found the lowest in the birds feeding on plants in our study $(0.56 \mathrm{mg} / \mathrm{kg})$. However, it was observed high in Great Bustard and Grey Partridge species feeding on seeds in agricultural fields and located in areas where agricultural pesticides are extensively used (Table 1).

\section{Conclusion}

The main purpose of this study is to determine the mercury level accumulated in feathers of the bird species living in terrestrial and aquatic ecosystems of Van Lake Basin located in the Eastern Region of Turkey. This study is the region's first heavy metal study conducted on the birds. In this study, the highest mercury concentration was detected in the Accipitridae family at the top of the food web (chain) with raptor species feeding in agricultural areas. Four raptor bird species that lives in rural habitats (Gypaetus barbatus, Neophron percnopterus, Otis tarda, Vanellus vanellus) were within the endangered species of the IUCN category.

With this study, it was suggested that the mercury level is correlated with nutrition style and habitat characteristics. While, the mercury level was found high for the regions of Van Lake Basin with agricultural activities and city pollution, it was determined that the species living in rural and high-altitude areas without pollution have lower mercury levels.

As the mercury concentrations detected in feathers reflect the amounts in their blood, they reveal the risk the species are exposed to. At the same time, it provides insight on other groups of the food web at lower steps of the birds.

\section{REFERENCES}

[1] Adızel, Ö., Durmuş, A., Kiziroğlu, İ. (2010): Preliminary study on newly detected yayliyaka marshes in the Lake Van Basin, Turkey. - The Journal of Animal and Plants Sciences 20(4): 286-292.

[2] Battaglia, A., Ghidini, S., Campanini, G., Spaggiari, R. (2005): Heavy metal contamination in little owl (Athene noatua) and common buzzard (Buteo buteo) from northern Italy. - Ecotoxicol. Environ. 60: 61-66.

[3] Behrooz, R. D., Esmaili-Sari, A., Ghasempouri, S. M., Bahramifar, N., Covaci, A. (2009): Organochlorine pesticide and polychlorinated biphenyl residues in feathers of birds from different trophic levels of south-west Iran. - Environment International 35: 285-290.

[4] Blust, R., Van der Linden, A., Verheyen, E., Decleir, W. (1988): Evaluation of microwave heating digestion and graphite furnace atomic absorption spectrometry with 
continuum source background correction for the determination of $\mathrm{Fe}, \mathrm{Cu}$ and $\mathrm{Cd}$ in brine shrimp. - J Anal Spectrom 3: 387-393.

[5] Braune, B. M., Gaskin, D. E. (1987): Mercury levels in Bonaparte's gulls (Larus philadelphia) during autumn molt in the Quoddy region, New Brunswick, Canada. Archives of Environmental Contamination and Toxicology 16: 539-549.

[6] Burger, J. (1993): Metals in avian feathers: bioindicators of environmental pollution. Reviews of Environmental Contamination and Toxicology 5: 203-311.

[7] Burger, J. (1996): Heavy metal and selenium levels in feathers of Franklin's gulls in interior. - North America Auk 113: 399-407.

[8] Burger, J. (2002): Food chain differences affect heavy metals in bird eggs in Barnegat Bay, New Jersey. - Environmental Research Section A 90: 33-39.

[9] Burger, J. (2013): Temporal trends (1989-2011) in levels of mercury and other heavy metals in feathers of fledgling great egrets nesting in Barnegat Bay, NJ. - Environmental Research 122: 11-17.

[10] Burger, J., Gochfeld, M. (1997): Risk, mercury levels, and birds: relating adverse laboratory effects to field biomonitoring. - Environ Res 75: 160-172.

[11] Cardiel, I. E., Taggart, M. A., Mateo, R. (2011): Using $\mathrm{Pb}-\mathrm{Al}$ ratios to discriminate between internal and external deposition of $\mathrm{Pb}$ in feathers. - Ecotoxicology and Environmental Safety 74: 911-917.

[12] Cifuentes, J. M., Becker, P. H., Sommer, U., Pacheco, P., Schlatter, R. (2003): Seabird eggs as bioindicators of chemical contamination in Chile. - Environmental Pollution 126: $123-137$.

[13] Dauwe, T., Bevoets, L., Blust, R., Pinxten, R., Ense, R. (2000): Can excrement and feather of nestling song-birds be used as biomonitors for heavy metal pollution? - Arch. Environ. Contam. Toxicology 39: 541-546.

[14] Dauwe, T., Bervoets, L., Pinxten, R., Blust, R., Eens, M. (2003): Variation of heavy metals within and among feathers of birds of prey: effects of molt and external contamination. - Environ. Pollution 124: 429-436.

[15] Dudka S, Miller, W. P. (1999): Accumulation of potentially toxic elements in plants and their transfer to human food chain. - J Environ Science Health B 34: 681-708.

[16] Furness, R. W., Muirhead, S. J., Woodburn, M. (1986): Using bird feathers to measure mercury in the environment: relationships between mercury content and moult. - Mar. Pollution Bulletin. 17: 27-30.

[17] Furness, R. W., Johnston, J. L., Thompson, D. R. (1989): Pollutant Burdens and Reproductive Success of Golden Eagles (Aquila chryaetos) Exploiting Marine and Terrestrial Food Webs in Scotland. - In: Meyburg, B. U., Chancellor, R. D. (eds.), Raptors in the Modern World, pp. 495-500. WWGBP, Berlin.

[18] Goede, A. A., De Bruin, M. (1984): The use of bird feather parts as a monitor for metal pollution. - Environ. Pollution 8: 281-298.

[19] Goutner, V., Furness, R. W., Papakostas, G. (2001): Mercury in feathers of squacco heron (Ardeola ralloides) chicks in relation to age, hatching order, growth, and sampling dates. - Environ. Pollution 111: 07-115.

[20] Janssens, E., Dauwe, T., Bervoets, L., Eens, M. (2001): Heavy metals and selenium in feathers of great tits (Parus major) along a pollution gradient. - Environmental Toxicology and Chemistry 20: 2815-2820.

[21] Jaspers, V., Tom, D., Rianne, P., Lieven, B., Ronny, B., Marcel, E. (2004): The importance of exogenous contamination on heavy metal levels in bird feathers. A field experiment with free-living great tits (Parus major). - Journal of Environmental Monitoring 6: 356-360.

[22] Manjula, M., Mohanraj, R., Devi, M. P. (2015): Biomonitoring of heavy metals in feathers of eleven common bird species in urban and rural environments of Tiruchirappalli, India. - Environ Monit Assess 187: 267. 
[23] Mashroofeh, A., Riyahi Bakhtiari, A., Ghobeishavi, A., Ahmadpour, A., Asadi, A., Ahmadpour, M., Hosseini, S. H., Eskandari, T., Burger, J. (2015): Mercury levels in avian feathers from different trophic levels of eight families collected from the northern region of Iran. - Environ Monit Assess 187: 275.

[24] Metcheva, R., Yurukova, L., Bezrukov, V., Beltcheva, M., Yankov, Y., Dimitrov, K. (2010): Trace and toxic elements accumulation in food chain representatives at Livingston Island (Antarctica). - Int J Biol 2: 155-161.

[25] Monteiro, L. R., Furness, R. W. (1995): Seabirds as monitors of mercury in the marine environment. - Water Air and Soil Pollution 80: 831-870.

[26] Movalli, P. A. (2000): Heavy metal and other residues in feathers of laggar falcon (Falco biarmicus juggar) from six districts of Pakistan. - Environ. Pollut. 109: 267-275.

[27] Muralidharan, S., Jayakumar, G., Vishnu, G. (2004): Heavy metals in feathers of six species of birds in the district Nilgris, India. - Bull. Environ. Contam. Toxicol. 73: 285291.

[28] Nergiz, H., Durmuş, A. (2017): Effects of Habitat Change on Breeding Waterbirds in Arin (Sodali) Lake, Turkey. - Applied Ecology and Environmental Research 15(3): $1111-1118$.

[29] Nriagu, J. O., Pacyna, J. M. (1988): Quantitative assessment of worldwide contamination of air, water and soils by trace metals. - Nature 333: 134-139.

[30] Stewart, F. M., Phillips, R. A., Bartle, J. A., Craig, J., Shooter, D. (1999): Influence of phylogeny, diet, molt schedule and sex on heavy metal concentrations in New Zealand Procellariiformes. - Marine Ecology Progress Series 178: 295-305.

[31] Xiuhua, T., Jinjun, W., Guangyin, Z., Yongqiang, N., Tongzu, Z. (1998): Observation on Ultra-micro Structure of Eggshell and Analysis of Composition of Eggshell and Feather in Great Bustard. - Journal of Foreslry Research 9(2): 87-90.

[32] Zolfaghari, G., Esmaili-Sari, A., Mahmoud, G. S., Kiabi, H. (2007): Examination of mercury concentration in the feathers of 18 species of birds in southwest Iran. Environmental Research 104: 258-265. 